\title{
CHRM4 Gene
}

National Cancer Institute

\section{Source}

National Cancer Institute. CHRM4 Gene. NCI Thesaurus. Code C24297.

This gene plays a role in G protein-coupled receptor signal transduction, and may play a role in adenylyl cyclase inhibition. 